$\stackrel{\odot}{11}$

\title{
HUMANISTYKA AKADEMICKA W DOBIE POSTNAUKI. KILKA UWAG O FILOZOFII REFORM SZKOLNICTWA WYŻSZEGO W POLSCE
}

\begin{abstract}
Andrzej Wawrzynowicz, Humanistyka akademicka w dobie postnauki. Kilka uwag o filozofii reform szkolnictwa wyższego w Polsce [Academic humanities in the era of post-science. Some remarks on the philosophy of higher education reforms in Poland] edited by Zbigniew Drozdowicz, Sławomir Sztajer, "Człowiek i Społeczeństwo” vol. LII: Globalne i lokalne problemy życia akademickiego [Global and local problems of academic life], Poznań 2021, pp. 91-106, Adam Mickiewicz University. ISSN 0239-3271, https://doi.org/10.14746/cis.2021.52.5.
\end{abstract}

The aim of the paper is to discuss the current status of academic humanities (specifically philosophy) in the modern system of science and higher education. The recent structural reforms carried out in this sector in Poland had the ambitious goal of bringing the Polish universities in line with the current trends observed in academic education systems in developed countries, and improving the global competitiveness of Polish science. The article is an attempt at a critical confrontation of these strategic intentions with the actual effects achieved through the reforms, primarily in the context of the profound transformations of the very concept of science that has historically accompanied these changes. In particular, the paper presents a methodological analysis of the impact of the postulated new interpretation of research on the scientific status to date - and the prospects for further development - of traditional humanistic disciplines.

Keywords: humanities, philosophy, methodology, knowledge management, post-science

Andrzej Wawrzynowicz, Uniwersytet im. Adama Mickiewicza w Poznaniu, Wydział Filozoficzny, ul. Szamarzewskiego 89c, 60-568 Poznań, e-mail: andrzej.wawrzynowicz@amu.edu.pl, ORCID: https:// orcid.org/0000-0001-9198-7901. 


\section{Wprowadzenie}

W opracowaniu podjęte zostało zagadnienie miejsca humanistyki akademickiej w zreformowanym systemie nauki i szkolnictwa wyższego (por. Brzeziński, 2020). Przeprowadzone w minionej dekadzie dwie duże reformy tego sektora gruntownie przebudowują organizację badań naukowych i strukturę funkcjonowania uczelni publicznych. Programowym celem zmian jest dostosowanie polskiego uniwersytetu do aktualnych tendencji w ewolucji systemów państw najbardziej rozwiniętych, głównie zachodnioeuropejskich, i podniesienie konkurencyjności nauki polskiej w świecie. Twórcy reform nie ukrywają, że humanistyka nie leży w centrum zainteresowania i w zakresie priorytetowych celów tej transformacji systemowej. Ale priorytetem tym nie jest także nauka jako taka, przynajmniej w jej tradycyjnym (kontynentalnym) pojęciu europejskim. Tradycyjne rozumienie myślenia naukowego - oparte źródłowo na klasycznej koncepcji prawdy Arystotelesa, rozwijane w toku kilkusetletniej historii szkolnictwa uniwersyteckiego w Europie, a finalnie zinstytucjonalizowane w nowoczesnym modelu uniwersytetu humboldtowskiego - jest już według tych założeń anachronizmem (por. Kwiek, 2010: 45, 356; 2015: 47). Tekst Ustawy z dnia 20 lipca 2018 r. Prawo o szkolnictwie wyższym i nauce ${ }^{1}$ nieustannie odwołuje się do terminologii ekonomicznej, wielokrotnie posługuje się pojęciem „gospodarka”, termin „humanistyka” natomiast użyty zostaje w tekście ustawy tylko dwa razy (i to w wersji przymiotnikowej). Nie jest to przypadek. Badania naukowe nie mają tu już bowiem pełnej autonomii względem ekonomii, lecz traktowane są jako segment życia gospodarczego (Kwiek, 2010: 380) i jako takie powinny w myśl twórców założeń reform przede wszystkim służ y ć gospodarce². Idea wolnej nauki, niepoddanej kontroli ze strony władzy politycznej, jest zgodnie z tym poglądem reliktem ery nowożytnej, niedostosowanym do globalnych wyzwań ponowoczesnego świata i rosnącej międzynarodowej

${ }^{1}$ Dz.U. 2018, poz. 1668, dalej: Ustawa 2.0.

${ }^{2}$ Wyrazem tego jest charakterystyczna wiara w czystą bezstronność i obiektywizm ocen eksperckich opartych wyłącznie na formalnych procedurach, przy jednoczesnej nieufności wobec funkcji merytorycznych ciał kolegialnych (przede wszystkim dawnych rad wydziałów, a obecnie rad dyscyplin naukowych), i wynikająca z tego redukcja pojęcia autonomii badań naukowych do centralistycznie pojętej koncepcji autonomii sprawowania władzy administracyjnej przez rektorów uczelni za pomocą powoływanych przez nich prorektorów, dziekanów, dyrektorów i kierowników niższego szczebla. 
konkurencji. Dziewiętnastowieczny uniwersytet europejski pojęty tradycyjnie, jako instytucja kształcenia ogólnego i formowania elit państwa narodowego, efektywnie nie spełnia już swojej właściwej funkcji, ponieważ gwałtownie zmienia się architektonika otoczenia społecznego (por. Kwiek, 2010: 352-376). Obiektywnej dynamice przemian ekonomicznych, polityczno-społecznych i kulturowych w świecie ery globalizacji towarzyszą gruntowne przewartościowania filozoficzne głównego nurtu myśli zachodniej. Koda tych historycznych przewartościowań - europejska (zwłaszcza francuska) i amerykańska filozofia postmodernistyczna - przygotowuje pośrednio teoretyczny grunt pod radykalnie zrewidowany sposób podejścia do zagadnienia nauki i wiedzy. Kwintesencją tego podejścia jest paradygmat ekonomicznego zarządzania wiedzą w nauce (por. Boguski, 2013; por. także Grudzewski i Hejduk, 2005), który zasadniczo zmienia dotychczasową pozycję humanistyki akademickiej. Artykuł zawiera próbę krytycznej rekonstrukcji filozofii tych zmian.

\section{Granice naturalizmu metodologicznego w nauce}

Postmodernistyczna radykalizacja antynaturalizmu metodologicznego (por. Musiał, 2016: 558-560) podważyła stabilność wszelkich trwałych rozróżnień pojęciowych w naukach humanistycznych. Pokazała, że humanistyka nie ma bezpośrednich podstaw własnej tożsamości dziedzinowej i zawieszona jest $\mathrm{z}$ tego tytułu w nieusuwalnym niedookreśleniu metodologicznym oraz towarzyszącej mu chronicznej płynności pojęć. Przyjmująca ten wyrok główna linia kontynentalnej filozofii europejskiej pośrednio ugruntowała tym samym od wewnątrz wszystkie wcześniejsze próby zakwestionowania własnego statusu naukowego podejmowane zewnętrznie, przede wszystkim na gruncie anglosaskiej tradycji myśli analitycznej - próby, które opierały się na czysto intuicyjnym jeszcze, choć mimo to wiele mówiącym rozróżnieniu typologicznym: science i humanities. Aktualna reaktywacja naturalizmu metodologicznego (por. Musiał, 2016: 558-560) w nowej, skrajnie neopragmatystycznej odsłonie doprowadza fenomenologiczny proces erozji tego statusu do końca. Wypływające z dynamiki tego procesu stanowisko współczesnej ekonomii zarządzania wiedzą naukową - prezentowane w pozornie neutralnej epistemologicznie i aksjologicznie formie interdyscyplinarnych badań porównawczych nad nauką i szkolnictwem wyższym (por. Kwiek, 2010: 25-26, 38-42; 2015: 44-47) - zawdzięcza w istocie wiele tej warunkującej ją postmodernistycznej autodestrukcji metodologii filozofii i nauk 
humanistycznych w ogóle. Z metodologicznego punktu widzenia można nawet zaryzykować stwierdzenie, że jest ono rodzajem praktycznej egzekutywy tej autodestrukcji - wyrazem swoistego skoku postmodernizmu od dotychczasowej ponowoczesnej teorii (tylko) do praktyki (por. Kwiek, 1994: 67 i n.).

\section{Problem amerykańskiej hegemonii gospodarczej i technologiczno- -naukowej w świecie i jej historyczne konsekwencje}

Założenia programowe Ustawy 2.0 - ustawy określanej oficjalnie przez jej politycznych rzeczników i entuzjastów dość patetycznym (i sformułowanym nieco na wyrost) mianem „Konstytucji dla Nauki” - zdradzają głęboką fascynację amerykańską hegemonią w nauce. Jest to nastawienie tkwiące implicite $\mathrm{w}$ forsowanym $\mathrm{w}$ tych założeniach korporacyjnym modelu organizacji i zarządzania nauką i szkolnictwem wyższym (por. Kwiek i in., 2016: 33-34), opartym na osłabieniu kierowniczej funkcji kolegialnych rad naukowych i zastąpieniu jej silnie scentralizowaną władzą menedżerską, zabezpieczoną kordonem rad powierniczych (por. Kwiek i in., 2016: 37; Radwan, 2017: 46 i n.; Antonowicz, 2018), a w finalnym kształcie ustawy tzw. rad uczelni. Pełnią one w myśl założeń programowych reformy de facto rolę analogiczną do funkcji rad nadzorczych w przedsiębiorstwach i korporacjach biznesowych (por. art. 19 ust. 1 i 2 Ustawy 2.0), utrwalając model rozwoju bliski dominującym w ostatnich latach tendencjom ewolucji systemu amerykańskiego w tym zakresie (por. Kościelniak, 2019: 187 i n.). Nastawienie to obecne jest także explicite w publikacjach i publicznych wypowiedziach twórców założeń programowych reformy (por. zwł. LUMEN, 2021).

Warto odnieść się do szerszego, globalnego wymiaru tej hegemonii. Należy zaakcentować w tym kontekście co najmniej cztery istotne kwestie.

Po pierwsze, dominacja gospodarki i nauki amerykańskiej w świecie w dekadę po upadku „żelaznej kurtyny”, czyli pod koniec XX w., stała się historycznym faktem, z którym nikt w Europie właściwie już nie dyskutuje. Przemawiają za nim obiektywne wskaźniki ekonomiczne. Przedmiotem zainteresowania elit zachodnioeuropejskich stało się natomiast poszukiwanie systemowych dróg wyjścia, czyli zdefiniowanie potencjalnych czynników dynamicznego rozwoju ekonomicznego pozwalających na pożądaną w tych okolicznościach historycznych aktywizację Starego Kontynentu i sprostanie wymogom konkurencji transatlantyckiej, zwłaszcza na trudnym i wymagającym rynku nowoczesnych technologii. Obiektywną reakcją państw Unii 
Europejskiej na ten fakt był między innymi proces boloński, zainaugurowany podpisaniem w czerwcu 1999 r. Deklaracji Bolońskiej, oraz szeroki kontekst działań politycznych podjętych najpierw w marcu 2000 r. przez Radę Europejską, a następnie kontynuowanych przez Radę Unii Europejskiej i Komisję Europejską w ramach szeroko zakrojonego planu rozwojowego strategii lizbońskiej (Lisbon Strategy), którego zasadniczym celem miało być „stworzenie w Europie najbardziej dynamicznej i konkurencyjnej w skali globalnej gospodarki opartej na wiedzy, zapewniającej zrównoważony rozwój, charakteryzujący się m.in. poprawą warunków zatrudnienia i harmonią społeczną” (Kraśniewski, 2009: 68).

Po drugie, warto podkreślić jeszcze inny, niebudzący raczej sporu fakt, że ekonomiczne i polityczno-społeczne efekty realizacji planu okazały się finalnie porażką. W ciągu planowanych dziesięciu lat nie zdołano usunąć luki w rozwoju gospodarczym pomiędzy Unią Europejską a Stanami Zjednoczonymi i zrealizować zasadniczych celów strategii lizbońskiej, takich jak programowy wzrost nakładów na badania i rozwój naukowy do poziomu 3\% PKB. W rezultacie w roku 2010 Unia Europejska przyjęła nową strategię - program Europa 2020. Warto dodać na marginesie, że bieżący rok 2021 znajduje się już (przynajmniej chronologicznie) właściwie poza wyjściowym horyzontem strategii Europa 2020 czy przyjętego przez Parlament Europejski i Radę Unii Europejskiej w grudniu 2013 r. związanego z nią programu ramowego Horyzont 2020. Można powiedzieć, że rok wybuchu globalnej pandemii nie tyle pokrzyżował finalną realizację tej nowej-starej strategii, co raczej uchronił ją przed gruntowną krytyką, jakiej dekadę wstecz nie uniknęła jej lizbońska poprzedniczka).

W związku z tym, po trzecie, rodzi się naturalne pytanie, czy dwie ostatnie reformy sektora nauki i szkolnictwa wyższego w Polsce (które weszły w życie, odpowiednio, w 2010 i 2018 r.) okazują się rzeczywiście adekwatną odpowiedzią na globalne wyzwania współczesności początku trzeciej dekady XXI w., czy raczej tylko projekcją historycznych wyzwań (i odpowiedzi na nie) z okresu przełomu XX i XXI stulecia? Ta druga możliwość sugerowałaby, że były one w istocie reakcją spóźnioną i z dzisiejszego punktu widzenia nieadekwatną. I nie chodzi tu wyłącznie o ogólny rezonans oraz długofalowe efekty ekonomiczne i polityczne pandemii COVID-19. Ogólnoświatowa epidemia ujawniła jedynie obiektywne skutki procesu głębokich zmian w globalnej sytuacji międzynarodowej, jakie politolodzy amerykańscy, np. John J. Mearsheimer, diagnozowali już całe dwie dekady temu (por. Mearsheimer, 2019), a elity intelektualne i polityczne po obu stronach oceanu włączyły w agendę własnych działań w ostatnich latach 
(por. Strittmatter, 2020) ${ }^{3}$. O ile więc dwadzieścia lat temu, w momencie uruchomienia procesu bolońskiego, realizacja - przykładowo - idei budowy Europejskiego Obszaru Szkolnictwa Wyższego miała jeszcze oparcie w, reliktowej już co prawda, ale mimo to ciągle jednak racjonalnej, wierze w jednolinearny postęp nauko-techniczny świata (por. Fukuyama, 2004: 284 i n.), o tyle obecnie tego oparcia już de facto nie ma.

Po czwarte, quasi-normatywny rys teorii zarządzania nauką, który ukrywany jest pod powierzchnią „,neutralnych” i czysto „opisowych” analiz ilościowych, nie bierze pod uwagę aktualnych na gruncie nowszych badań społecznych diagnoz krytycznych dotyczących samego pojęcia „zarządzanie wiedzą" - pojęcia, które we wspomnianych analizach jest nadal pozytywnie waloryzowane w sposób niezwykle naiwny i bezkrytyczny. Współczesna filozofia i psychologia społeczna wskazują na obiektywne zagrożenia dla przyszłości całego demokratycznego ładu światowego, płynące już nie tyle z bezpośredniej ekspansji politycznej czy militarnej lokalnych reżimów politycznych bądź regionalnych totalitaryzmów państwowych, co raczej z pośrednich skutków dynamiki rozwoju wysokich technologii informatycznych tworzących metapolityczne instrumenty i mechanizmy pozademokratycznej władzy i ideologicznej kontroli ze strony globalnych struktur korporacyjnych (por. Zuboff, 2020: 676-677). Trudno dostrzec obecność narzędzi teoretycznych, za pomocą których obecna ekonomia zarządzania wiedzą w nauce mogłaby ochronić własne wyniki badawcze przed niebezpieczeństwem dowolności i arbitralności generowanej siłą tego rodzaju zagrożeń.

\section{Internacjonalizm i klientyzm}

Krytyka tradycyjnego, quasi-feudalnego modelu kariery akademickiej (por. Kwiek, 2015: 22, 36), opartego na hierarchii stopni i tytułów naukowych oraz wspartego organizacyjnie funkcją zamkniętego systemu rad naukowych, wypromowała bezpośrednie przeciwieństwo tego modelu - mit kariery w pełni „demokratycznej” i „otwartej”. Ten nowy, wyidealizowany

${ }^{3}$ Dostrzeżenie Chin jako globalnego gracza w polityce międzynarodowej, potencjalnie równorzędnego Stanom Zjednoczonym hegemona regionu Azji i zachodniego Pacyfiku zbiegło się w czasie w minionych latach z kadencją Donalda Trumpa i z procesem oficjalnego już niemal kwestionowania przez Francję i Niemcy (oraz znaczną część środowiska wysokich urzędników unijnych) amerykańskiego przywództwa politycznego w świecie zachodnim, w którego tle rozgrywała się jednocześnie dynamika spektakularnego wyjścia Zjednoczonego Królestwa ze struktur Unii Europejskiej. 
tu model ścieżki naukowej nie jest jednak wcale wolny od konieczności zdefiniowania obiektywnych kryteriów oceny wartości konkretnych dokonań badawczych. Dotychczasowa, zindywidualizowana odpowiedzialność dawnych hierarchów akademickich w tym zakresie zastąpiona zostaje nietransparentną rolą struktur redakcyjnych, rozmaitych rad programowych i ciał definiujących kryteria rekrutacji członków grup eksperckich - a więc zastąpiona zostaje w istocie pewną formą odpowiedzialności zbiorowej. Tego rodzaju posunięcie jest (w sensie epistemologicznym) regresywnym powrotem do ideału naturalistycznie rozumianego „obiektywizmu” naukowego. Ktoś musi bowiem podejmować ostatecznie także realne decyzje rozstrzygające w nauce (w kwestiach finansowych, awansowych itd.) i tym faktorem w omawianym modelu kariery naukowej jest czynnik polityczny, czyli w praktyce - odpowiedzialny za resort nauki członek rządu, tzn. odpowiedni minister czy podsekretarz stanu. Walka z quasi-feudalną zależnością badacza od zhierarchizowanych struktur naukowych świata akademickiego okazuje się więc skuteczna jedynie za cenę bezpośredniego podporządkowania nauki nie mniej zhierarchizowanym strukturom świata polityki.

Destrukcyjne skutki tego epistemologicznego regresu dają o sobie znać szczególnie dotkliwie w naukach humanistycznych. Wieloetapowy proces weryfikacji obiektywnej jakości naukowej dorobku badawczego (np. artykułu naukowego) ma bowiem, w myśl tego, także i tu sens wtedy i tylko wtedy, gdy istnieją naturalnie określone „bezstronne” kryteria takiej obiektywności. Tymczasem liczne stanowiska w szerokim nurcie dwudziestowiecznych badań z zakresu antynaturalistycznej epistemologii humanistyki pokazują dobitnie, że takie kryteria po prostu nie istnieją.

Warto przeanalizować definicję pojęcia umiędzynarodowienia, którym twórcy założeń reformy posługują się jako uniwersalnym kluczem do sukcesu naukowego, pozwalającym podnieść aktualny, nieredukowalnie „peryferyjny” jeszcze, jak się tu zakłada, rys charakteru polskiej nauki do poziomu i rangi przyszłego światowego „centrum” tego rodzaju działalności (por. Kwiek, 2015: 18-19, 36-44, 331 i n.).

Pojęcie umiędzynarodowienia badań zawiera w sobie co najmniej trzy odmienne postulaty metodologiczne, przyjęte tu jako wyjściowe założenia przebudowy całego modelu uprawiania i ewaluacji działalności naukowej w Polsce. Pierwszy i najważniejszy z tych postulatów to zalecenie tworzenia prac naukowych we współczesnej lingua franca, czyli w języku angielskim (rozumianym jako uniwersalny język nauki). Postulat ten formułowany jest w tym przypadku w integralnej łączności (jako swoisty warunek sine qua non) z drugim postulatem, którym ma być „obiektywna” konfrontacja 
(na arenie międzynarodowej) wyników prac polskich naukowców z aktualnym „światowym” stanem badań w zakresie poszczególnych dyscyplin. Trzecim postulatem, założonym w tym modelu w istocie jako pochodna efektywnej realizacji dwóch poprzednich postulatów, jest popularyzacja dorobku polskiej nauki. Twórcy reformy nie przywiązują szczególnej wagi do wzajemnego rozróżnienia tych trzech postulatów tworzących zasadnicze komponenty pojęcia umiędzynarodowienia, ponieważ przyjmują (świadomie, półświadomie lub całkowicie bezwiednie) dominujący tradycyjnie w świecie anglosaskim wzorzec myślenia naukowego w kategoriach naturalizmu metodologicznego. Wzorzec, który - w sensie teoretycznym - jest już obecnie (przynajmniej na gruncie filozofii) przeszłością. W ramach tego naturalizmu przyjmuje się jako założenie wyjściowe, że podstawowe normy i dyrektywy metodologiczne są wspólne dla nauk przyrodniczych oraz humanistycznych. Typowy dla europejskiej (zwłaszcza niemieckiej i francuskiej) tradycji kontynentalnej paradygmat myśli antynaturalistycznej w tym zakresie (Wilhelm Dilthey, neokantowska szkoła badeńska, Max Weber, teoria krytyczna, poststrukturalizm), a także przetaczający się przez całą historię filozofii nauki XX w. wielopoziomowy spór teoretyczny w tym zakresie, zakończony spektakularnym podważeniem twardych epistemologicznych podstaw naturalizmu (Willard Van Orman Quine), a następnie swoistą neopragmatystyczną autodestrukcją tych podstaw (w postmodernizmie Richarda Rorty'ego) - wszystko to nie znajduje dostatecznego odbicia w konkretnych regulacjach prawnych Konstytucji dla Nauki. To zatem, co dla filozofów tworzących założenia programowe ostatnich reform nauki i szkolnictwa wyższego w Polsce musiało być skądinąd wiedzą oczywistą (por. Kwiek, 1994; 1999), dla prawników implementujących te założenia w formie konkretnych zapisów ustawowych stanowi najwyraźniej obszar terra incognita.

Stosowana tu definicja umiędzynarodowienia w nauce nie jest neutralna aksjologicznie - ma ona w tym przypadku wyraźne zabarwienie etnocentryczne, preferujące w sposób nadrzędny autorów publikujących w języku angielskim. Nie jest to zatem wskaźnik aktywności naukowej (w tym zwłaszcza „publikowalności”) obcojęzycznej, lecz anglojęzycznej. Jeżeli więc, zgodnie z tą optyką, potraktujemy umiędzynarodowienie jako pojęciowy ekwiwalent „wysokiej jakości naukowej” w ogóle - ze względu na zawarte w nim założenie spełnienia wymogu obiektywnej, międzynarodowej konfrontacji wyników badań - to okazuje się, że badacz będący naturalnym użytkownikiem języka angielskiego spełnia wymóg umiędzynarodowienia (a tym samym zakładany tu podstawowy warunek wysokiej jakości naukowej) niejako a priori, tzn. zanim skonfrontuje efektywnie treść 
własnych badań z dorobkiem badawczym konkurencji na jakimkolwiek gruncie obcojęzycznym, a nawet niezależnie od tego, czy zrobi to kiedykolwiek. Takie proste utożsamienie wartości naukowej opublikowanego tekstu z czysto socjometrycznie pojętym wskaźnikiem umiędzynarodowienia daje niewątpliwie wygodne narzędzie ewaluacji naukowej, które stwarza pozór procedury opartej na neutralnych aksjologicznie kryteriach analizy czysto ilościowej. Niemniej jednak jest to tylko złudzenie. Niezależnie od (być może dobrych) intencji forsujących tę konwencję ekspertów - takie podejście oznacza de facto ideologiczną promocję autorów pochodzących naturalnie z jednego kręgu etniczno-językowego i dyskryminację wszystkich pozostałych, a granicznie także wykluczenie znacznej części tych drugich. Ta ostatnia sugestia nie jest zarzutem trudnym do empirycznego zilustrowania. Przykład systemowego wykluczenia wynikającego z przyjęcia takich wąsko socjometrycznych kryteriów ewaluacji dorobku naukowego stanowią liczne subdyscypliny nauk filologicznych, historycznych czy filozoficznych.

\section{Czy nauka ma narodowość?}

Centralnym elementem opisu obecnej fazy historycznych przeobrażeń idei badań naukowych i wynikającej z niej koncepcji szkolnictwa wyższego jest - w zarysowanej tu optyce interdyscyplinarnych badań nad nauką i szkolnictwem wyższym - opozycja pojęciowa między lokaln y m (ang. local) a mi ędzynarodowym (ang. international) wymiarem działalności badawczej (por. Kwiek, 2015: 331 i n.). Warto przyjrzeć się bliżej tej opozycji, ponieważ stanowi ona klucz do zrozumienia semiotycznych uwarunkowań omawianego tu wariantu ekonomii zarządzania wiedzą w nauce. Opozycja ta stanowi w istocie zbitkę dwóch innych par przeciwstawnych pojęć, mianowicie opozycji między tym, co lokalne i globalne oraz t y m, c o na ro d o w e (wzgl. nacjonalne, nacjonalistyczne) i międzyn a r o d o we (wzgl. internacjonalne, internacjonalistyczne). Bezpośrednio wydaje się zatem, że można ją zastąpić którąś z tych dwóch opozycji. Ale po bliższej analizie okazuje się, że tak nie jest, przede wszystkim dlatego, że pierwszy człon tej pary - lokalny aspekt badań naukowych - waloryzowany jest tu z góry negatywnie, drugi zaś człon - aspekt międzynarodowy tych badań - waloryzowany jest jednoznacznie pozytywnie. Próba zastąpienia tej pary pojęć opozycją lokalny - globalny stwarzałaby w warunkach wspomnianej waloryzacji niekorzystne wrażenie bezkrytycznej promocji ideologii globalizmu w nauce. Z kolei zastąpienie jej opozycją 
narodowy - międzynarodowy wywoływałoby, zwłaszcza u naturalnego użytkownika języka angielskiego, uformowanego w angloamerykańskiej tradycji myśli politycznej, pewien dysonans poznawczy. Słowo narodowy (ang. national) nie ma na gruncie języka angielskiego i angloamerykańskiej tradycji myśli politycznej wydźwięku bezpośrednio pejoratywnego. Termin ten sam w sobie ma tu znaczenie neutralne i budzi pozytywne skojarzenia, figurując na przykład z tego tytułu w nazwach wielu ważnych instytucji państwowych Stanów Zjednoczonych. Negatywna konotacja tego terminu silnie obecna od XX stulecia w myśli europejskiej (głównie kontynentalnej) pod wpływem traumatycznych doświadczeń historycznych Europy związanych z nazizmem - nie przeniknęła efektywnie na grunt języka angielskiego. Reasumując: opozycja lokalny - międzynarodowy okazuje się tu w pewnym sensie terminologicznie nie do zastąpienia. Mimo to czerpie w tym przypadku z tej swojej, zarysowanej powyżej, pojemności znaczeniowej w sposób dość swobodny, unikając jedynie (ryzykownego w tym kontekście) czynienia nadmiernego użytku z terminu narodowy.

Nadmierne eksponowanie faktu, że w zakres pojęcia „tego, co lokalne” wchodzi tu zarazem szeroki kontekst znaczeniowy terminu „narodowy”, stwarza pewne trudności semiotyczne również na gruncie języka polskiego. Ze względu na historyczne wypieranie tego terminu z polityczno-prawnego języka oficjalnej nomenklatury PRL-owskiej i zastępowanie go zabarwionym ideologicznie w ówczesnych warunkach terminem „państwowy”, termin „narodowy” przeżywa w ostatnich latach w Polsce swoisty renesans. Jako, praktycznie, synonim terminu „państwowy”, ale pozbawiony tamtego ideologicznego zabarwienia historycznego, występuje teraz między innymi jako integralny człon nazw najważniejszych instytucji naukowych państwa polskiego (np. Narodowe Centrum Nauki) czy flagowych programów badawczych (jak Narodowy Program Rozwoju Humanistyki). Także prawdopodobnie z tego powodu musi być on w terminologii charakteryzowanej tu teorii zarządzania nauką w pewnym sensie „na cenzurowanym”. Trudno bowiem byłoby w tych warunkach efektywnie przypisać mu konotację jednoznacznie negatywną w opozycji do terminu „międzynarodowy”.

\section{Ideologia wzrostu naukowego produktu krajowego brutto}

W rzeczywistości nie chodzi tu jednak wbrew pozorom o wyeliminowanie, czy nawet jakieś istotne ograniczenie „narodowego” wymiaru twórczości naukowej w ogóle, lecz raczej o radykalną zmianę sposobu oceny 
wartości tej twórczości. Dotychczasowe kryteria jakościowe mają zostać zastąpione kryteriami ilościowo-formalnymi. Celem nadrzędnym ma być pełna instrumentalizacja efektów pracy naukowca, jako forma stymulacji czynników wzrostu dobra ogólnego. Nauka traci tym samym właściwy walor poznawczy, przestaje być domeną autonomicznie pojętej wiedzy i staje się odtąd efektywnym składnikiem gospodarki rynkowej (tzn. bezpośrednio - gospodarki krajowej, a pośrednio - globalnej). Jako taka, podlega zaś ostatecznie waloryzacji wyłącznie w kategoriach użyteczności praktycznej - tak, jak ją w danym momencie (czyli zgodnie z aktualnym widzimisię) rozumiemy. Bogate i zasobne społeczeństwa północnej i zachodniej Europy mogą oczywiście zasadniczo pozwolić sobie, w myśl tego sposobu myślenia, na względnie szeroką interpretację, a więc i rozluźnienie podstawowego kryterium oceny wartości użytkowej określonych typów naukowej działalności badawczej (np. humanistycznej). Nie zmienia to jednak generalnie faktu, że tak pojęta nauka staje się teraz czymś, co zawsze i w każdym przypadku służy odtąd jedynie czemuś zewnętrznemu wobec niej, nigdy zaś suwerennej zasadzie własnej, czyli klasycznie rozumianej prawdzie - bo tej, w myśl owego metateoretycznego poglądu założonego tu w punkcie wyjścia, po prostu nie ma.

\section{Dialektyczne prawo przechodzenia ilości w jakość}

Efektem takiego podejścia jest dyrektywa postulująca „produkowanie” wysoko indeksowanych tekstów naukowych bez względu na ogólny profil teoretyczny czasopisma oraz waloryzowanie później szczegółowych wyników tej „produkcji” w całokształcie dorobku naukowego danego pracownika, z całkowitym pominięciem roli jakościowej oceny miejsca tekstu w rozwoju reprezentowanej przez tego pracownika dziedziny badawczej. Skoro liczy się głównie wynik indywidualnego wkładu (punktowego) pracownika do globalnej parametryzacji wydziału czy uczelni, to wchodzenie w jakieś, „drugorzędne” $\mathrm{z}$ tego punktu widzenia, jakościowe kwestie merytoryczne staje się irracjonalne i niecelowe. Zwłaszcza że za tym wynikiem idzie automatycznie (wdrażany również w tym modelu) motywacyjny system wynagradzania uczelni czy takie parametry polityki kadrowej jak ogólne warunki konkursowe zatrudnienia pracowników na etat. W ten sposób - ujmując rzecz całą w formę pewnej historiozoficznej paraboli - zaczyna się realizować w dzisiejszej praktyce naukowej to, czego, mimo wsparcia i wieloletnich wysiłków kilku pokoleń przedstawicieli socjalizmu naukowego minionej 
epoki, nie udało się uzasadnić teoretycznie wpływowej niegdyś koncepcji materializmu dialektycznego Fryderyka Engelsa, mianowicie „prawo przechodzenia ilości w jakość” (Engels, 1972: 412).

\section{Synteza neoliberalizmu z neomarksizmem}

Ta egzotyczna fuzja założeń współczesnego neoliberalizmu i neomarksizmu tworzy źródłowy background radykalnie „nowego” spojrzenia na historyczny rozwój wiedzy ludzkiej. Pod klasyczne marksistowskie założenie, że „byt społeczny określa świadomość”, można bowiem z łatwością podstawić jego współczesny pankonsumpcjonistyczny odpowiednik, a mianowicie zasadę, że to nie tyle byt, co raczej dobrobyt społeczny określa tęże świadomość. O ile jednak to pierwsze (marksistowskie) przekonanie daje się jeszcze częściowo obronić teoretycznie, przynajmniej jako odkrycie faktu nieredukowalnego uwarunkowania bezpośredniego wszelkiej myśli ludzkiej w jej historycznym rozwoju, o tyle ta druga zasada, podnosząca ją do rangi uwarunkowania o st at e c z n e go, jest już w istocie bezpodstawna. Obie zasady abstrahują przy tym całkowicie od tego, jak predefiniowany jest źródłowo sam dobrobyt, tzn. jak zmienia się jego definicja w dynamicznym procesie przekraczania kolejnych stopni rozwoju świadomości jednostkowej i ogólnej w dziejach i jak nieustannie rewidowane są w efekcie wszystkie wcześniejsze wyobrażenia na ten temat na długiej drodze historycznego postępu ludzkości. Efektem tego jest ideologiczna hybryda, która łączy (najwyraźniej bezwiednie) pewne elementy klasycznej marksistowskiej teorii działania społecznego z komponentem późnokapitalistycznego liberalizmu konsumpcjonistycznego - liberalizmu wierzącego w nieskończony postęp ludzkości w kierunku (bliżej nieokreślonego i nieustannie tu odsuwanego w mglistą przyszłość) globalnego dobrobytu ogólnego.

4 „Sposób produkcji życia materialnego warunkuje społeczny, polityczny i duchowy proces życia w ogólności. Nie świadomość ludzi określa ich byt, lecz przeciwnie, ich byt społeczny określa ich świadomość” (Marks, 1949: 338). 


\section{Od postpolityki ${ }^{5}$ do postnauki?}

Jaki obraz rzeczywistości naukowej utrwala finalnie (choć być może nie jest to jeszcze definitywny koniec tego historycznego procesu) realizowany w Polsce od ponad dekady wieloetapowy proces przyspieszenia reform strukturalnych sektora nauki i szkolnictwa wyższego oraz dostosowania go do globalnych standardów? Oceniając to z perspektywy dyscyplin humanistycznych, w szczególności filozofii europejskiej modelu kontynentalnego perspektywy odmiennej, dodajmy, od dominującej w środowisku ekspertów od ekonomii zarządzania wiedzą optyki ukierunkowanej na prymat badań stosowanych i wdrożeniowych nad badaniami podstawowymi (tj. teoretycznymi, czystymi) w nauce ${ }^{6}$, ekspertów pozostających dodatkowo jeszcze, co nie jest tu bez znaczenia, pod silnym wpływem anglosaskiej tradycji myśli analitycznej $^{7}$ - ten obraz jest dość czytelny. Proponuje on uwolniony od wszelkich jakościowych regulacji, skrajnie zderegulowany neoliberalny świat (ilościowej) rywalizacji o uznanie zdefiniowane jako abstrakcyjne miejsce w czysto formalnym rachunku naukowego prestiżu. Nie chodzi w nim już o prawdę i krytyczne dochodzenie do niej ani o jakkolwiek rozumiane humanistyczne wartości przekazu naukowego, lecz o abstrakcyjne samopotwierdzenie indywidualnego podmiotu działalności badawczej. Podmiotu, który „bada” własne miejsce w statystykach, kontroluje swoją

${ }^{5}$ Próbę filozoficznego opracowania tego zagadnienia zawiera artykuł Pawła Kusiaka Postpolityka. W poszukiwaniu istoty zjawiska (2011).

${ }^{6}$ Warto dodać, że w zakres dyscyplin p od s ta w o w y ch (tj. teoretycznych, czystych) - w odróżnieniu od dziedzin s t o s o w a n y ch, takich jak w szczególności nauki inżynieryjne, informatyka, medycyna (i jej hybrydy, np. biotechnologia), ale także nauki ekonomiczne, polityczne i prawne - wchodzą tradycyjnie zarówno nauki przyrodnicze oraz ścisłe, jak i społeczne oraz humanistyczne. Trzecim segmentem działalności badawczej w ogólnej typologii badań naukowych ze względu na cel są badania wdrożen i o we. Taki sposób rozumienia badań podstawowych znajduje odbicie również w obowiązujących obecnie w Polsce regulacjach prawnych (por. art. 4 ust. 2 pkt 1 Ustawy 2.0).

7 Jeżeli na tę typologię nałożymy bliską tej tradycji ramową siatkę podziału nauk na science i humanities, to nauki humanistyczne usunięte zostają automatycznie poza ten opis i trafiają w swoistą typologiczną próżnię, nie mieszcząc się właściwie w żadnej z trzech wymienionych kategorii nauk: podstawowych, stosowanych czy wdrożeniowych. Tłumaczy to dość charakterystyczną dla badaczy pozostających pod silnym wpływem tradycji myśli analitycznej tendencję do wykluczania dyscyplin humanistycznych i społecznych z zakresu nauk podstawowych i w efekcie zaliczania do tych ostatnich wyłącznie dyscyplin przyrodniczych i ścisłych. 
bieżącą pozycję w strukturze korporacyjnej, zabezpiecza sieciowe kontakty osobiste umożliwiające utrzymanie tej pozycji w przyszłości i zbiera zewnętrzne oznaki uznania tak zdefiniowanego wysokiego statusu naukowego - uznania, z jednej strony, potwierdzanego czynnie w hermetycznie zamkniętym, elitarnym środowisku doświadczonych uczonych i ekspertów (publikujących swój dorobek wyłącznie w największych i najbardziej renomowanych wydawnictwach oraz czasopismach z górnego piętra wykazów punktowanych periodyków naukowych), a z drugiej - znajdującego bierne potwierdzenie w szerokim, egalitarnym kręgu „młodzieży” akademickiej, pływającej wokół jak plankton i dopiero aspirującej do udziału w pracach tego ekskluzywnego gremium.

Nowa organizacja nauki i szkolnictwa wyższego nie wspiera efektywnie tego, co jest tętnem rzetelnej i odpowiedzialnej pracy w dziedzinie nauki (por. Brzeziński, 2020: 191-195) - aktywnego udziału w konferencjach i seminariach, recenzowania tekstów naukowych, tworzenia specjalistycznych zespołów do realizacji długofalowych projektów badawczych, troski o wszechstronny rozwój młodej kadry akademickiej. Fakt, że taka tradycyjna praca jest w dalszym ciągu wykonywana, wynika jedynie z naturalnego odstępu czasowego, jaki oddziela moment realnego wprowadzenia reform w życie od (opóźnionego zwykle nieco) momentu pełnej konceptualizacji w środowisku (w tym przypadku akademickim) systemowych skutków tych zmian. Nowe, radykalnie odwrócone wektory oceny wartości działalności badawczej w nauce zostały już jednak usankcjonowane jako obowiązujące regulacje prawne. Kompleksowe ukierunkowanie na utrzymanie jakościowych standardów dyskursu naukowego w otwartej debacie uniwersyteckiej wypierane jest obecnie instytucjonalnie przez promocję czysto ilościowego kryterium efektywności badawczej, mierzonej wskaźnikiem popularności cytowań i liczby punktów w rankingu branżowego uznania - kryterium niepodlegającego już żadnej merytorycznej ocenie i bezkrytycznie hołdującego interdyscyplinarnej impakto- i punktomanii (por. Rykiel, 2014: 24; Zabel i in., 2014; Szczerbowski, 2017: 85) ${ }^{8}$. Efektem takiej agendy (umocowanej prawnie w regulacjach ustawowych organizujących rzeczywistość badań naukowych i sposób funkcjonowania szkolnictwa wyższego) jest sytuacja,

${ }^{8}$ O procesie semantycznego zawłaszczania przez ekspertów współtworzących uprzednio administracyjny system „punktozy” samego dyskursu krytycznego opisującego to negatywne zjawisko w polskiej nauce pisze Wojciech Włoskowicz w artykule Nowomowa pseudometanaukowa? O języku polskiej polityki naukowej (2019: 36, 44-45; por. także Kulczycki, 2017). 
w której specjaliści z dziedziny nauk humanistycznych rezygnują z pracy badawczej w zakresie własnej dyscypliny (np. filozofii) i budują swoją pozycję i karierę akademicką na analizach socjometrycznych publikowanych w (wysoko) punktowanych periodykach branżowych z tego obszaru. Agenda ta nie wspiera zatem realnie także forsowanej tu oficjalnie idei umiędzynarodowienia badań naukowych, lecz raczej przenosi działalność naukową w rzeczywistość swoistej p o s t n a u k i.

\section{Literatura}

Antonowicz, D. (2018). Rady powiernicze w szkolnictwie wyższym. Nauka i Szkolnictwo Wyższe, 1(51), 45-68.

Boguski, J. (2013). Zarządzanie wiedzą w uczelni wyższej. Nauka i Szkolnictwo Wyższe, 2(42), 10-31.

Brzeziński, J.M. (2020). O miejsce przy stole... Państwo wobec nauk humanistycznych i społecznych. Człowiek i Społeczeństwo, 49: Humanistyka jutra, 175-196.

Engels, F. (1972). Dialektyka przyrody, tłum. T. Zabłudowski. W: K. Marks, F. Engels, Dzieła, t. 20 (ss. 365-674). Warszawa: Książka i Wiedza.

Fukuyama, F. (2004). Koniec człowieka. Konsekwencje rewolucji biotechnologicznej, tłum. B. Pietrzyk. Kraków: Wydawnictwo Znak.

Grudzewski, W.M., Hejduk, I. (2005). Zarządzanie wiedzą w organizacjach. E-mentor, 1(8). http://www.e-mentor.edu.pl/artykul/index/numer/8/id/115 (dostęp: 29.05.2021).

Kościelniak, C. (2019). Przemiany idei uniwersytetu. Warszawa: Wydawnictwo Naukowe PWN.

Kraśniewski, A. (2009). Proces Boloński. To już 10 lat. Warszawa: Fundacja Rozwoju Systemu Edukacji.

${ }^{9}$ W związku z tym, że forsujący Ustawę 2.0 obóz polityczny dochodził do władzy na fali programowego sprzeciwu wobec koncepcji p ostpolity ki, której hołdowała do pewnego stopnia poprzednia formacja rządząca, rodzi się pytanie, czy konieczną ceną za ten ideowy powrót do myślenia politycznego w kategoriach klasycznej filozofii polityki jest właśnie skrajne zerwanie z tradycyjnie pojętą filozofią nauki i wkroczenie na grunt po s t n a u ki, czy też może jest raczej tak, iż rzeczywistość p o s tn a u kow a wyłania się obecnie jako swoista restytucja bądź zradykalizowana wersja myślenia p o s tp o lit y c zn e g o. W pierwszym przypadku oznaczałoby to de facto instytucjonalizację, a zarazem uogólnienie do obszaru całej humanistyki akademickiej procesu historycznego, który Andrzej Radomski opisuje jako charakterystyczny rys rozwoju współczesnych nauk o kulturze związany z „nowym rozumieniem działalności wiedzotwórczej - postnaukowej właśnie” (Radomski, 2008: 142). W drugim przypadku byłoby to natomiast pośrednie potwierdzenie filozoficznych intuicji Slavoja Žižka, który w swojej koncepcji p o stpolity ki integralnie łączy to pojęcie z historycznym fenomenem postmodernizmu (por. Žižek, 1999: 84-89). 
Kulczycki, E. (2017). Punktoza jako strategia w grze parametrycznej w Polsce. Nauka i Szkolnictwo Wyższe, 1(49), 63-78.

Kusiak, P. (2011). Postpolityka. W poszukiwaniu istoty zjawiska. Colloquium, 3, 157-180.

Kwiek, M. (1994). Rorty i Lyotard. W labiryntach postmoderny. Poznań: Wydawnictwo Naukowe Instytutu Filozofii Uniwersytetu im. Adama Mickiewicza w Poznaniu.

Kwiek, M. (1999). Dylematy tożsamości. Wokół autowizerunku filozofa w powojennej myśli francuskiej. Poznań: Wydawnictwo Naukowe Instytutu Filozofii Uniwersytetu im. Adama Mickiewicza w Poznaniu.

Kwiek, M. (2010). Transformacje uniwersytetu. Zmiany instytucjonalne i ewolucje polityki edukacyjnej w Europie. Poznań: Wydawnictwo Naukowe UAM.

Kwiek, M. (2015). Uniwersytet $w$ dobie przemian. Instytucje i kadra akademicka w warunkach rosnqcej konkurencji. Warszawa: Wydawnictwo Naukowe PWN.

Kwiek, M., Antonowicz, D., Brdulak, J., Hulicka, M., Jędrzejewski, T., Kowalski, R., Kulczycki, E., Szadkowski, K., Szot, A., Wolszczak-Derlacz, J. (2016). Projekt założeń do ustawy Prawo o szkolnictwie wyższym. Poznań: Uniwersytet im. Adama Mickiewicza w Poznaniu.

LUMEN 1 na 1. Podcast \#2. Zarządzanie nauką (2021). https://www.youtube.com/ watch?v=XGDIped9k2A (dostęp: 29.05.2021).

Marks, K. (1949). Przyczynek do krytyki ekonomii politycznej. Przedmowa. W: K. Marks, F. Engels, Dzieła wybrane, t. 1 (ss. 336-340). Warszawa: Książka i Wiedza.

Mearsheimer, J.J. (2019). Tragizm polityki mocarstw, tłum. P. Nowakowski, J. Sadkiewicz. Kraków: Towarzystwo Autorów i Wydawców Prac Naukowych „Universitas”.

Musiał, G. (2016). Poznańska Szkoła Metodologiczna - jej rozwój i znaczenie. Przeglq̨d Filozoficzny, 2(98), 553-563.

Radomski, A. (2008). Kulturoznawstwo jako postnauka. W: A. Pankowicz, J. Rokicki, P. Plichta (red.), Tożsamość kulturoznawstwa (ss. 133-143). Kraków: Wydawnictwo Uniwersytetu Jagiellońskiego.

Radwan, A. (red.) (2017). Plus ratio quam vis consuetudinis. Reforma nauki i akademii w Ustawie 2.0. Projekt założeń do ustawy Prawo o szkolnictwie wyższym. Kraków: Oficyna Allerhanda.

Rykiel, Z. (2014). Szaleństwo czy metoda? Modernizacja przez biurokratyzację i prekaryzację. Przestrzeń Społeczna, 4/2(8), 7-60.

Strittmatter, K. (2020). Chiny 5.0. Jak powstaje cyfrowa dyktatura, tłum. A. Gadzała. Warszawa: Wydawnictwo WAB.

Szczerbowski, T. (2017). Punktoza jako słowo ostatnich lat. Poradnik Językowy, 7, 80-87.

Włoskowicz, W. (2019). Nowomowa pseudometanaukowa? O języku polskiej polityki naukowej. Poradnik Językowy, 10, 35-47.

Zabel, M., Rafajłowicz, E., Dahlig-Turek, E., Hanke, W., Mach, B., Brzeziński, P. (2014). Punktoza, czyli wskaźniki bibliometryczne stosowane przez KEJN w ocenie parametrycznej jednostek naukowych. Forum Akademickie, 9. https://prenumeruj. forumakademickie.pl/fa/2014/09/punktoza/ (dostęp: 29.05.2021).

Zuboff, S. (2020). Wiek kapitalizmu inwigilacji. Walka o przyszłość ludzkości na nowej granicy władzy, tłum. A. Unterschuetz. Poznań: Zysk i S-ka Wydawnictwo.

Žižek, S. (1999). Raduj się swoim narodem, jak sobą samym, tłum. A. Chmielewski. Nowa Krytyka, 10, 49-97. 